\title{
Injury Characteristics among the Cricket Trainees of Bangladesh Krira
}

\section{Shikkha Protishtan (BKSP)}

\author{
Mohammad Najmul Hossain ${ }^{* 1}$ (D) Md. Robiul Islam² (D), Md.Rejwan Gani Mazumder ${ }^{3}$ (D) \\ ${ }^{1}$ Enam Medical College \& Hospital, Savar, Dhaka-1340, Bangladesh \\ ${ }^{2}$ Labaid Diagnostic Pvt. Ltd. Pallabi, Mirpur, Dhaka, Bangladesh \\ ${ }^{3}$ SAIC College of Medical Science \& Technology (SCMST), Mirpur, Dhaka, Bangladesh \\ *Correspondence: Counselor (Operation Logistics \& Budget), Enam Medical College \& Hospital, Savar, Dhaka-1340, \\ Bangladesh, najmulphysio@gmail.com
}

\begin{abstract}
Introduction: Cricket is a popular, well-known, and most played common sport in Bangladesh which is dynamic, complex, and vulnerable to injuries. Objective: To find out the common sports injuries among the professional cricket playing students of Bangladesh Krira Shikkha Protisthan (BKSP). Methodology: This was a cross-sectional study with 70 students from the cricket section of BKSP. Data has been collected with a semi-structured survey questionnaire from January to June 2019. Result: The results showed most of the participants are in their second decade of life and the highest percentage of participants age was 20 $(27.1 \%)$, similarly height $(\mathrm{cm})$ mean and standard deviation $(167.43 \pm 5.157)$ and found the highest percentage of participant's height $27 \mathrm{~cm}(38.5 \%)$. The weights of the respondents were $65.514 \pm 7.539 \mathrm{~kg}$ and BMI of the respondent were $23.311 \pm 2.048$. Major playing site $82.9 \%(\mathrm{n}=58)$ were batsman, $60 \%(\mathrm{n}=42)$ were bowlers and $18.6 \%(\mathrm{n}=13)$ were in wicketkeeper. The study found $55.7 \%(n=39)$ of the respondents had upper limb injury, 22.9\% ( $n=16)$ had rotator cuff injuries, 10\% ( $=7$ ) had tennis elbow, $10 \%$ (7) had acute soft tissue injuries, $10 \%$ (7) had an ankle sprain and $21.4 \%$ (15) had cuff muscle pull. Conclusion: The study found upper limb injuries are most common than lower limb injuries for the cricket trainees in Bangladesh. Moreover, the shoulder is one of the most vulnerable sites of injuries.
\end{abstract}

Keywords: BKSP, Cricket Trainee, Sports injury

Background

Cricket in Bangladesh is a popular, thriving, throbbing, vibrant passion for Bangladeshi people [1]. Because of its popularity, millions of people following and playing Cricket all over the globe. Nowadays, Elite sports players train themselves harder, longer, and make them keep fit, whatever the consequences; they want to cope up [2]. For this instance, the three major areas in cricket like Batting, Bowling, and fielding are not free from the risk of injury [3]. Novice and young players tend to be a major risk of injury [4]. Bowling has a relationship with the major cause of cricket injuries sustaining with back injuries of the schoolboy about $38 \%$ and $47.4 \%$ [2]. In Bangladesh research is scarce in findings of cricket, however, a survey is conducted with 10 different sports areas among 391 students of BKSP where found the percentage of injury is more at cricket, football, and hockey. The common injury they suffer from a groin strain, neck pain, shin splint, Osgood-
Schlatter's disease, patellofemoral joint disorder [5]. An evident show during the final event most common injuries occur as Hamstring strain as load and challenge are increased in this stage [6]. Hamstring injuries are the most widely recognized single sort of injury speaking to $12-37 \%$ of all things considered [7]. During matches, the greater part of injury happens in muscle wounds (53\%) and $47 \%$ during preparation. There are ninety-two percent of all muscle injuries influenced the 4 significant muscle gatherings of the lower limbs - hamstrings (37\%), adductors (23\%), quadriceps (19\%), and lower leg muscles (13\%) and Sixteen percent of the muscle injuries were re-injuries [6]. The anatomical sites of injuries in cricket have been accounted for in various investigations. Injuries to the lower limbs shifted from $22.8 \%$ to $50.0 \%$ [8]. Upper limb injuries represented $19.8-34.1 \%$ of total injuries, with the fingers, saw as the most vulnerable site. Back and trunk wounds represented about $18 \%$ and $33.3 \%$ separately of the wounds. 
The occurrence of injury to the head, neck, and face shifted from $5.4 \%$ to $25 \%[9,10]$. These injuries comprised principally of concussions, contusions, and lacerations. This article aims to explore the common sports injuries for young cricket trainees; which will be helpful for Bangladeshi cricketer and coaches for future direction.

\section{Methodology}

This is a cross-sectional survey conducted at Bangladesh Krira Shikkha Protishtan (BKSP) from January to June 2019. The data were obtained by face to face interview. The inclusion criteria were cricket trainees at BKSP, the age range was: 13- 25 years old, and who are willing to participate in the study. A pre-tested modified semistructured questionnaire has been used which were prepared based on objectives and different variables of this study.

\section{Statistical Analysis}

The collected data were evaluated by descriptive analysis and some quantitative data were analyzed by using the software SPSS 16.0 version (Chicago). Then analyzed data were presented according to the variables of the study showing the percentage relationship between variables by appropriate statistical method. Descriptive statistics have been used to analyze and present the data.

\section{Results}

The mean age of the respondents was $17 \pm 2.063$ years with a range from 13 to 21 years. The result shows highest age was $20(27.1 \%)$, height $(\mathrm{cm})$ was $146-150 \mathrm{~cm}(38.5 \%)$, weight was $41-45 \mathrm{~kg}(30 \%)$ and BMI shows $78.6 \%$ of the respondents were healthy (18.5-24.99), $18.6 \%$ were overweight $(\geq 30)$ and $2.8 \%$ were underweight $(<18.5)$ respectively. The mean BMI of the respondent were 23.311 2.048. Details are appended in table 1 .

Table 1: Distribution of Personal information $(n=70)$

\begin{tabular}{|c|c|c|}
\hline & Frequency & Percentage \% \\
\hline Age (years) & \multicolumn{2}{|c|}{$17 \pm 2.063$} \\
\hline Mean \pm SD & 8 & 11.5 \\
\hline $13-15$ & 19 & 27.2 \\
\hline $16-18$ & 43 & 61.4 \\
\hline $19-21$ & \multicolumn{3}{|c|}{$146 \pm 5.157$} \\
\hline Height (cm) & \multicolumn{2}{|c|}{$46 \pm 7.539$} \\
\hline Mean \pm SD & \multicolumn{2}{|c|}{2.8} \\
\hline Weight (kg) & \multicolumn{2}{|c|}{$23.311 \pm 2.048$} \\
\hline Mean \pm SD & 2 & \\
\hline BMI & \multicolumn{2}{|c|}{} \\
\hline Mean \pm SD & Under Weight \\
$(<18.5)$ & & \\
\hline
\end{tabular}

\begin{tabular}{|c|c|c|}
\hline $\begin{array}{c}\text { Healthy (18.5- } \\
24.99)\end{array}$ & 55 & 78.6 \\
\hline $\begin{array}{c}\text { Over Weight } \\
(25-29.99)\end{array}$ & 13 & 18.6 \\
\hline Obese $(\geq 30)$ & 0 & 0 \\
\hline
\end{tabular}

$82.9 \%$ of the respondents were batsmen, $60.0 \%$ were bowlers, and $18.6 \%$ were wicketkeepers. There were multiple responses. $92.9 \%$ of the respondents were playing regularly and $7.1 \%$ of the respondent were not playing cricket regularly. Among the Players, $91.4 \%$ of the respondents had experienced injuries. There was diversity like injuries. Figure 1 reveals that $18.6 \%$ of the respondent had Head \& Neck injury, $7.1 \%$ had Neck pain, $7.1 \%$ had Sports Concussion, $7.1 \%$ had Epistaxis, $55.7 \%$ of the respondents had Upper limb injury, 50\% had Lower Limb injury, $7.1 \%$ had Thorax / Chest injury \& 92.9\% had the experience of Skin Laceration injury respectively. As there were multiple responses, from a higher level to lower level of multiple sites of Injury were as Skin Laceration > Upper Limb Injury > Lower Limb Injury > Head \& Neck Injury > Neck Pain, Sports Concussion, Epistaxis \& Thorax Injury respectively.

Figure: 1 Distribution of responded by the site of injury and nature of injury (Multiple Responses)

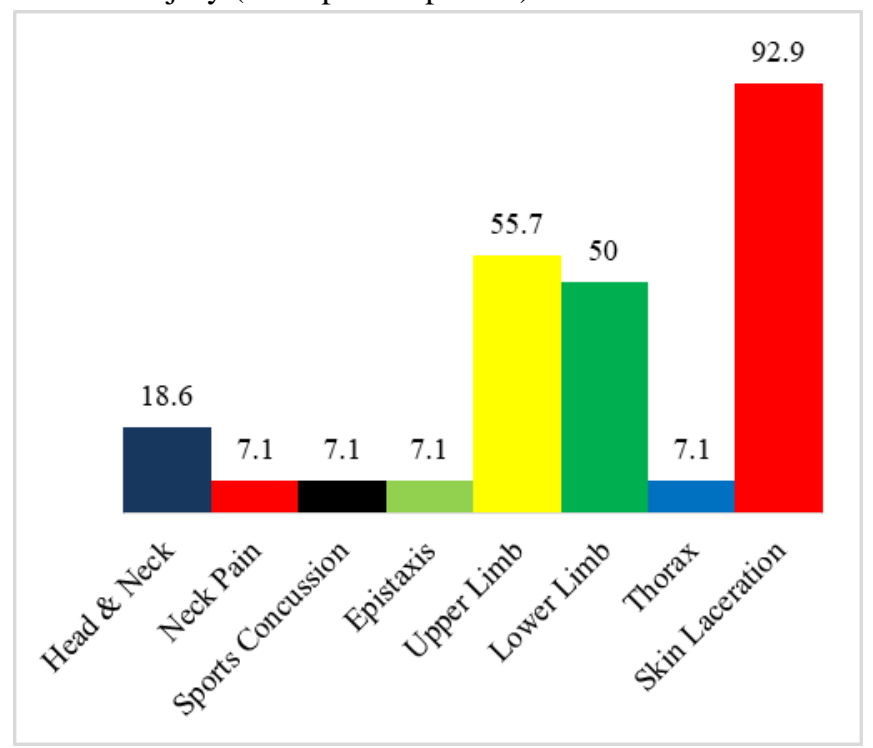

Analyzing the characteristics of injuries, Table 2 found that, $22.9 \%$ of the respondents had Rotator cuff injuries, $5.7 \%$ had shoulder instability and $4.3 \%$ had shoulder dislocation injury. $10 \%$ of the respondents had Tennis elbow \& $5.7 \%$ had Golfers elbow, $10 \%$ of the respondents had Acute Soft Tissue injuries, $5.7 \%$ had Dislocation of Hand joints \& $1.4 \%$ had Fracture of Phalanges. Also, 5.7\% of the respondents had meniscus injuries, $4.3 \%$ had ACL tears \& $10 \%$ had Acute Soft Tissue Injury of the Knee joint. Among the 
respondents, $10 \%$ had Ankle sprain, 5.7\% Corns \& calluses, $1.4 \%$ Deltoid ligament injury \& $1.4 \%$ plantar fasciitis. Moreover, $21.4 \%$ of the respondents had Cuff muscle pull, $17.1 \%$ Hamstring pull, $8.6 \%$ back muscle strain, $1.4 \%$ Neck muscle strain.

Table 2: Characteristics of the Injuries (Multiple Responses)

\begin{tabular}{|c|c|c|}
\hline $\begin{array}{l}\text { Shoulder joint } \\
\text { injuries }\end{array}$ & Frequency & $\begin{array}{c}\text { Percentage } \\
\%\end{array}$ \\
\hline Rotator cuff injuries & 16 & 22.9 \\
\hline $\begin{array}{l}\text { Shoulder joint } \\
\text { dislocation }\end{array}$ & 3 & 4.3 \\
\hline Shoulder instability & 4 & 5.7 \\
\hline Tennis elbow & 7 & 10 \\
\hline Golfers elbow & 4 & 5.7 \\
\hline $\begin{array}{lll}\begin{array}{l}\text { Acute } \\
\text { injury }\end{array} & & \\
\end{array}$ & 7 & 10 \\
\hline Fracture of Phalanges & 1 & 1.4 \\
\hline $\begin{array}{l}\text { Dislocation of Hand } \\
\text { joints }\end{array}$ & 4 & 5.7 \\
\hline Meniscus injury & 4 & 5.7 \\
\hline ACL tears & 3 & 4.3 \\
\hline $\begin{array}{l}\text { Acute Soft Tissue } \\
\text { Injury }\end{array}$ & 7 & 10 \\
\hline Ankle sprain & 7 & 10 \\
\hline $\begin{array}{l}\text { Deltoid ligament } \\
\text { injury }\end{array}$ & 1 & 1.4 \\
\hline Corns and calluses & 4 & 5.7 \\
\hline Plantar fasciitis & 1 & 1.4 \\
\hline Back muscle strain & 6 & 8.6 \\
\hline Hamstring pull & 12 & 17.1 \\
\hline Cuff muscle pull & 15 & 21.4 \\
\hline Neck muscle strain & 1 & 1.4 \\
\hline
\end{tabular}

Discussion

Cricket is a popular game in Bangladesh and many teenagers train themselves to be a cricketer. This descriptive type of cross-sectional study was conducted to assess the common sports injuries among the BKSP students at Zirani in Savar with a sample size of 70 . The study found that the mean age of the respondents was $17 \pm 2.063$ years with a range from 13 to 21 years. The result shows highest age was $20(27.1 \%)$, height $(\mathrm{cm})$ was $146-150 \mathrm{~cm}(38.5 \%)$, and weight was $41-45 \mathrm{~kg}(30 \%)$ and BMI shows $78.6 \%$ of the respondents were healthy (18.5-24.99), $18.6 \%$ were overweight $(\geq 30)$ and $2.8 \%$ were underweight $(<18.5)$ respectively. The mean BMI of the respondent were 23.311 \pm 2.048 . A similar study found where height age range among young players $19-24$ years $(45.2 \%)$ and BMI of healthy weight $18.5-24.9(52.9 \%)$ [11].

The study reveals that $91.4 \%$ of the respondents had injuries experience and $8.6 \%$ were not. These findings are similar to the study carried out previously [2]. It is revealed from the study that, $55.7 \%$ of the respondents had Upper limb injury,
50\% Lower Limb, 18.6\% Head \& Neck, 7.1\% Thorax, 7.1\% Epistaxis, $7.1 \%$ Sports Concussion respectively. This finding is similar to the study carried out by several studies [12-14]. The study shows that $92.9 \%$ of the respondents had Skin laceration, $7.1 \%$ Sports concussion, $7.1 \%$ \& $1.4 \%$ Neck pain respectively. This finding is similar to the study carried out by a study [10].

The study found that $22.9 \%$ of the respondents had Rotator cuff injuries, $5.7 \%$ shoulder instability, and $4.3 \%$ shoulder dislocation. These findings are similar to the study carried out by two studies [15-16]. It is revealed from the study that $10 \%$ of the respondents had Tennis elbow and $5.7 \%$ Golfers elbow. These findings are not similar or dissimilar with such literature reviews of this study. The study further shows that $10 \%$ of the respondents were Acute Soft Tissue injuries, $5.7 \%$ were Dislocation of hand joints and $1.4 \%$ was a fracture of phalanges respectively. These findings are dissimilar with the study carried out [17].

The study found that $5.7 \%$ of the respondents were menisci injuries, $4.3 \%$ were ACL tears and $1.4 \%$ were acute soft tissue injury respectively. A similar study was found in 2000 and $2010[13,18]$ This study reveals that among the respondents, $10 \%, 5.7 \%, 1.4 \%, 1.4 \%$ were Ankle sprain, Corns and calluses, Deltoid ligament injury, Plantar fasciitis respectively. A similar study was found in a study [18]. The study shows that $21.4 \%$ of the respondents were Cuff muscle pull, $17.1 \%$ Hamstring pull, $8.6 \%$ back muscle strain, $1.4 \%$ Neck muscle strain respectively. These findings are similar to the study finding carried out by frost and Chalmers study [19].

There might be several limitations in this study. First of all, the result of the study cannot be generalized to the whole population of cricket players of Bangladesh as the samples were collected only from BKSP, Zirani, Savar. This study has attempted to provide a few data, which are very little to represent the wider population of a cricket player in Bangladesh.

\section{Conclusion}

Injury recurrences create a burden to the future cricketers who are developing their skills in age-levels. The study explored various sites that are prone to injuries which will be helpful in the prevention and treatment of the injuries of trainee cricketers. Minimizing the injuries may improve their fitness and skills that may be reflected through their performances in the future.

Ethical Permission: Formal ethical permission was taken from BKSP. From the beginning of this research, the Helsinki guideline was followed. 


\section{Ethical ID: BKSP/DiSc/46378}

Consent: During data collection, the purpose and goal of the study thoroughly explained the participants and obtain individual consent.

Availability of Data: Data is available upon request.

Funding: It was a self-funded study

Competing Interest: Authors declare no conflict of interest.

References

1. Dasgupta S. Bangladesh Cricket: Scoring on Passion, but Little Else .... Sport in Society. 2007;10(1):162-181.

2. Stretch R. Cricket injuries: a longitudinal study of the nature of injuries to South African cricketers * Commentary. British Journal of Sports Medicine. 2003;37(>3):250-253.

3. Paul S. [Internet]. http://202.4.109.28:8080/xmlui/. 2013 [cited 29 October 2020]. Available from: http://hdl.handle.net/123456789/64.

4. Stretch, R., and Venter, D., 2003. Cricket injuries a longitudinal study of the nature of injuries in South African cricketers. South African Journal of Sports Medicine, 15(2), p.4.

5. JBKSP (2002). Cause of knee and ankle injury among BKSP student A survey. Journal of BKSP,4(2):108-117.

6. Ekstrand, J., Hagglund, M., and Walden, M., 2009. Injury incidence and injury patterns in professional football: the UEFA injury study. British Journal of Sports Medicine, 45(7), pp.553-558.

7. Ekstrand J., 2013. "Epidemiology of muscle injuries in soccer". Muscle Injuries in Sports, pp. 128-134.

8. Stretch RA., 1989. Injuries to South African cricketers playing at first-class level. Journal of the South African Sports Medicine Association, 4:320.

9. Temple R. 1982. Cricket injuries: fast pitches change the gentleman's sport. Physician and Sports Medicine, 10:186-92.

10. Ranson, C., Peirce, N., and Young, M., 2013.

Batting head injury in professional cricket: a systematic video analysis of helmet safety characteristics. British Journal of Sports Medicine, 47(10), pp.644-648.

11. Bipasha, F., Kamrujjaman, M., and Maleque, A., 2018. Cricket Injuries among Bangladeshi Female Cricketers. Elixir Orthopedics, [online] 123(2018), pp. 51888-51892. Available at: <https://www.elixirpublishers.com/articles/153872 7732_ELIXIR2018096346B.pdf> [Accessed 22 July 2020].

12. Orchard, J., 2002. Injuries in Australian cricket at first-class level 1995/1996 to 2000/2001 Commentary. British Journal of Sports Medicine, 36(4), pp.270-274.

13. Orchard, J., 2010. Changes to injury profile (and recommended cricket injury definitions) based on the increased frequency of Twenty 20 cricket matches. Open Access Journal of Sports Medicine, p.63.

14. Milson, N., Barnard, J., and Stretch, R., 2007. Seasonal incidence and nature of cricket injuries among elite South African schoolboy cricketers. South African Journal of Sports Medicine, 19(3), p.80.

15. Green, R., Taylor, N., Watson, L., and Ardern, C., 2013. Altered scapular position in elite young cricketers with shoulder problems. Journal of Science and Medicine in Sport, 16(1), pp.22-27.

16. Ranson, C., and Gregory, P., 2008. A shoulder injury in professional cricketers. Physical Therapy in Sport, 9(1), pp.34-39.

17. Mansingh, A., 2006. Injuries in West Indies cricket 2003-2004* Commentary $1 *$ Commentary 2. British Journal of Sports Medicine, 40(2), pp.119123.

18. Stretch, R., Bartlett, R., and Davids, K., 2000. A review of batting in men's cricket. Journal of Sports Sciences, 18(12), pp.931-949.

19. Frost, W., and Chalmers, D., 2012. Injury in elite New Zealand cricketers 2002-2008: descriptive epidemiology. British Journal of Sports Medicine, 48(12), pp.1002-1007. 
Bangladesh Physiotherapy Journal (BPJ)

ISSN (P): 1727-6748, ISSN (O): 2708-2962

Hossain, M. N. 2020

www.bpa-bd.org/bpj

Copyright $\odot 2020$ Mohammad Najmul Hossain et al. This article is distributed under the terms of the Creative Commons Attribution License which permits unrestricted use, distribution, and reproduction in any medium provided the original author(s) and original publisher are properly credited. 